\title{
Monetary Policy Reaction Function in Open Economy Version: Empirical Evidence in Case of Pakistan
}

\author{
Sulaiman D Muhammad ${ }^{1}$, Adnan Hussain ${ }^{2}$, Muhammad Ahsanuddin ${ }^{3}$, Shazia Kazmi ${ }^{4} \&$ Irfan Lal $^{5}$ \\ ${ }^{1}$ Department of Economics, Federal Urdu University of Arts, Science and Technology, Karachi, Pakistan \\ ${ }^{2}$ Department of Economics, Benazir Bhutto Shaheed University, Lyari, Karachi, Pakistan \\ ${ }^{3}$ Department of Economics, University of Karachi, Karachi, Pakistan \\ ${ }^{4}$ University of Karachi, Karachi, Pakistan \\ ${ }^{5}$ Institute of Business \& Technology-Biztek, Karachi, Pakistan \\ Correspondence: Irfan Lal, Lecturer, Institute of Business \& Technology-Biztek, Karachi, Pakistan. E-mail: \\ Irf_yoch@yahoo.com
}

Received: March 4, 2012

Accepted: April 19, 2012 Published: July 1, 2012

doi:10.5539/ass.v8n8p89

URL: http://dx.doi.org/10.5539/ass.v8n8p89

\begin{abstract}
Aftermath the globalization and financial liberalization the purpose of monetary policy deviates from economic growth to economic stabilization. Therefore monetary authority adjusts its policy rate in response to systematic changes in macroeconomic activities and business fluctuations. The rule which is followed to stable an economy at development path is called Taylor's rule. This study empirically investigates monetary policy reaction function in case of Pakistan by applying Taylor's rule (1993) nevertheless Johansan co integration test is employed for its open economy version. The monthly data from the period of January 2003 to December 2008 has been collected for the analysis. It is found that the coefficient of output gap and exchange rate gap are significant while coefficient of inflation gap is insignificant. The results depicted that inflation does not play significant role due to the monetary policy as such in the frame work of Pakistan's economy. Therefore inflation targeted monetary policy does not suggest for Pakistan. To analyze the stability of coefficient ROLLING WINDOW technique was employed as it is found that monetary authority adopted inflation targeted monetary policy after 2002 which was not suitable as this study has shown.
\end{abstract}

Keywords: Taylor's rule, inflation gap, output gap, exchange rate gap

\section{Introduction}

According to monetarist school of thought discretionary monetary policy plays a key role to accelerate economic growth and it has a greater advantage over the Rule based monetary policy (Taylor 1993). Kydland et.al (1977) and Gordon et.al (1983) have highlighted that discretionary monetary policy is timely inconsistent. They argue that inflation targeting monetary policy becomes inconsistent and dynamics of this policy are taking time towards long run adjustment. Barro and Gordon (1983) argued that monetary authority deviated from announced rule due to discretionary monetary policy which is considered as punishment of private agents in an economy and central bank faces reputation problem due to this continues process of discretionary monetary policy. Regarding this problem Rogoff (1985) pointed out the delegation of powers to central bank may be useful to come out from this problem and further advised that monetary authority focus on inflation targeting policy.

Walsh (1995) highlighted that feasible solution of the dynamics time inconsistency problem through setting the punishment criterion by monetary authority. All the past research confirm that rule base monetary policy is comparatively superior than discretion monetary policy but the problem arises that how does the Rule Based monetary policy can operate at practical stage. Taylor had designed a rule based monetary policy which resolved this problem in 1993, which was naive as well as applicable to design monetary policy. The Taylor's rule suggests that short run interest rate is the key tool to design the monetary policy. The Taylor's rule precises that when the economy is deviated from trend or potential level of output or the inflation is deviated from its targeted level then interest rate is used as a key tool to back inflation and output level to their stable path and give equal weight both policies object in monetary policy reaction function. In this way the monetary authority would be able to solve the 
problem of dynamics inconsistency of discretionary monetary policy and this naïve rule is very helpful to improve economic activities and adjust the economy at the path of development. The Taylor's rule does not create the problem of enforcement as suggested by Barro and Gordon (1983) and this rule is simply assessed by the agent outside the monetary authority, therefore Commented Rule is practically as well as technically possible.

The key object of monetary authority is to keep the economy at the path of development so the monetary policy stance is characterized as a quantitative measure whether a policy is expansionary, neutral or contractionary to achieve the objectives (stability in prices, exchange rate stability and economic growth). Accurate measurement towards the size of monetary policy is very essential for estimation of different theories of the transmission mechanism, (Bernanke and Milhove 1998).

Monetary policy is used to maintain the economy at stable path. To achieve this goal central bank has required relevant information. It is also robust and feasible in the view that commitment policy is verifiable. Meltzer (1987), McCallum (1988), Taylor (1993), Henderson and McKibbin (1993). Taylor (1993) designed the rule to conduct the monetary policy; according to the rule Federal Reserve sets the fund rate (tool of monetary policy) equal to real interest rate plus the deviation of targeted inflation, targeted output and targeted unemployment level. He suggested that rule shows the "good" in the view that it relates to the goal of monetary policy and it is very helpful to stabilize both output and inflation rate. The rule is described as follow:

$$
i_{t}=r^{*}+\pi_{t}+\alpha_{1} y_{t}+\alpha_{2}\left(\pi_{t}-\pi^{*}\right)
$$

Thus $\mathrm{r}^{*}$ denotes the long run real interest rate equilibrium through goods market, $\pi \mathrm{t}$ denotes the current inflation rate, $\pi^{*}$ denotes targeted inflation rate and yt denotes the deviation of output from its potential path.

\subsection{Monetary Policy in Pakistan}

Prior to 1990 s a monetary policy which was designed with the help of credit ceiling or the credit control and interest rate further at that time banking and financial systems were not competitive in Pakistan. Almost seventy percent commercial banks were in public sector. Almost it was a compulsion for banks and financial institutions to keep a part of their deposit and portfolios in treasury bills and other government securities and schemes (Stationary legal reserve) at sub market interest rate. Most of the state owned banks were bound to lend the loan to state owned enterprises irrespective of their financial, productivity and prime status. In the absence of competition in banking sector people found insignificant level of motivation to save therefore resource mobilization stuck off in the economy. Said monetary policy was at random and government had no maturity structure and plan towards the liquidity and return. Subsequently in 1990s Pakistan has got the momentum towards the reforms in financial sector and reframed the monetary policy by applying indirect approach which can be stated a policy based on market instrument to accomplish stability and sustainability of macroeconomic variables in the economy.

After 1995 Pakistan State Bank of Pakistan (SBP) switched over the monetary policy from direct to indirect approach. SBP has adopted the policy tools i.e. open market operation, window discount borrowing, CRR (Cash reserve ratio) and SLR (Stationary legal reserve) to determine the liquidity position of banking sector. SBP had strive to minimize direct government intervention and stress on market mechanism for the optimal allocation of financial resources and in order to improve resource mobilization and augment competition among the banks and financial institutions.

After concise debate about Taylor's Rule and monetary policy, we will proceed to theoretical modeling and hypothesis in sections 2 , section 3 will be allocated for econometric methodology data sources, $4^{\text {th }}$ section will be for result analysis and last section $5^{\text {th }}$ will be spaced for conclusion and policy recommendation.

\subsection{Hypothesis Addressed}

H1: a positive relationship between output growth gap and nominal interest rate.

$\mathrm{H} 2$ : a positive relationship between exchange rate gap and nominal interest rate.

H3: a negative relationship between unemployment gap and nominal interest rate.

H4: a positive relationship between inflation gap and nominal interest rate.

\subsection{Objective of This Study}

The focal object of this study is to evaluate the monetary policy reaction function in case of Pakistan. For this purpose Taylor's rule monetary reaction function has been employed to find out the importance of each goal of monetary policy in case of Pakistan. 


\section{Theoretical Modeling and Hypothesis}

This study has focused on Taylor's Rule to determine the policy rate of SBP, Inflation, Gross Domestic Production (GDP), Unemployment and exchange rate. IIP (Industrial Index of Production) was chosen as proxy of GDP coherent reason is non availability of monthly data of GDP. Taylor's Rule narrates change in nominal interest rate due to the change in output gap, change in inflation gap and change in unemployment gap. In an open economy it also incorporates with exchange rate gap in Taylor's Rule. It is therefore estimated value calculated as follow:

$$
y=\alpha+\beta t
$$

Where y denotes exogenous variable and $t$ denotes time. This equation is used to measure the potential value of independent variables. The estimated or potential value can be subtracted from the actual value to find output, inflation, unemployment and exchange rate gap. Taylor's Rule is written as following equation:

$$
i_{t}=\alpha_{1}+\alpha_{2}\left(\pi^{a}-\pi^{e}\right)+\alpha_{3}\left(e^{a}-e^{e}\right)+\alpha_{4}\left(G D P a-G D P{ }^{e}\right)+\alpha_{5}\left(\mu^{a}-\mu^{e}\right)
$$

Expected coefficient of output gap is positive when the actual output is greater than the potential output which signified that an economy is beyond the potential path and required to back its actual path by accelerating policy rate. Expected coefficient of unemployment is negative when actual unemployment is greater than natural rate than it is suggested that policy rate must be reduced to keep backing economy at natural unemployment rate. Expected coefficient of inflation gap is positive when actual inflation is above the targeted level then it is suggested that SBP should increase the policy rate to back inflation at its potential path. Expected coefficient of exchange rate gap coefficient is negative when current exchange rate is greater then estimated exchange rate then SBP should increase policy rate to appreciate home currency.

\section{Econometrics Methodology and Data Source}

In this study monthly data is being used for the defined variables for the period from 2003 to 2008 and the sources of the data are IFS (international financial statistics) and IMF (international monetary fund).

The model is multivariate therefore Johnson co-integration technique was applied to evaluate long run association among the selected variables. Mostly it is witnessed that empirically macroeconomic variables are found non stationary at level or in other words there is a positive or negative trend found in these series. Thus, the traditional technique of OLS (ordinary least square) method is not valid to find the relationship among the variables due to the trend in variables because it leads to spurious regression or non sense regression. Unless the trend or non stationary in series are not eradicated by taking first difference or second difference we cannot proceed to find the long run association among the variables, hence it is suggested that all the variables are integrated at same order then Johansen co integration technique is applied for series estimation. ADF (Augmented Dicky Fuller) unit root test is used to analyze the stationary or non stationary of the macroeconomics variables series, the equation of ADF test is as follows:

$$
\Delta Y_{t}=\alpha+\beta Y_{t-1}+t+\sum \beta_{2} \Delta Y_{t-k}+\mu_{t}
$$

Where $\mathrm{Y}_{t}$ exhibits a time series, $\Delta$ exhibitsa first difference operator, T exhibits a linear trend, $\alpha$ and $\beta$ are estimator of unit root equation and $\mu$ exhibits an error term. $\beta=0$ exhibits the null hypotheis of existence of unit root.

\section{Result Analysis}

Current development in the subject of econometrics highlighted that most of the macroeconomic variables are non stationary at the level as cited in above section 3 . The results derived from such models which lead to spurious regression and non sense regression or in other word it can be said that variables are found integrated on different order. Hence, it is imperative to analyze the stationary of the macroeconomics time series variables prior to evaluate the equilibrium relationship among these variables. Thus, the macroeconomic time series stationary is examined through the Unit Root Test. 
Table 1. Unit root test

\begin{tabular}{lll}
\hline Variables & $\begin{array}{l}\text { Level with intercept and } \\
\text { trend (lag length) }\end{array}$ & $\begin{array}{l}\text { First difference interceptt and } \\
\text { trend (lag length) }\end{array}$ \\
\hline Interest rate & $4.039859(1)$ & $6.47611^{*}(2)$ \\
$\left(\pi^{a}-\pi^{e}\right)$ Inflation gap & $5.465519(0)$ & $14.43551^{*}(0)$ \\
$\left(G D P^{a}-G D P^{e}\right)$ output gap & $1.276849(1)$ & $17.85066^{*}(2)$ \\
$\left(e^{a}-e^{e}\right)$ Exchange rate gap & $1.242848(1)$ & $4.765983^{*}(0)$ \\
$\left(\mu^{a}-\mu^{e}\right)$ Unemployment gap & $2.874407(0)$ & $7.138522^{*}(0)$ \\
\hline
\end{tabular}

Significant at 5\% level

It is found that non stationary exists in all the selected variables. The alternative hypothesis that the time series are stationary is rejected at the level of all the variables used in this study at 5 percent significant level at least. For the purpose to analyze stationary in variables the study used ADF equation with intercept and trend as discussed in section 3. After analyzing the stationary of variables at level in subsequent step we analysis the stationary at first difference. The finding of the first difference exhibits that all the variables are stationary at integrated order one at $5 \%$ significant level. Parenthesis value shows the lag length of variables.

Interpretation of $\mathrm{ADF}$ test shows that variables are integrated at order one therefore, our next step is to analyze the long run association among the variables. The Johansen co integration test has been applied to find out the long run association among the variables. The result of Johansen co-integration test is shown below:

Table 2. Johnson co integration test (Trace Value)

\begin{tabular}{llccc}
\hline Null Hypothesis & $\begin{array}{l}\text { Alternative } \\
\text { Hypothesis }\end{array}$ & $\begin{array}{l}\text { Maximum trace } \\
\text { statistics }\end{array}$ & 5\% critical value & $\begin{array}{l}\text { Probability (P } \\
\text { value) }\end{array}$ \\
\hline $\mathrm{r}=0$ & $\mathrm{r} \geq 1$ & $83.31050^{*}$ & 69.81889 & 0.0029 \\
$\mathrm{r}=1$ & $\mathrm{r} \geq 2$ & $49.74397 *$ & 47.85613 & 0.0329 \\
$\mathrm{r}=2$ & $\mathrm{r} \geq 3$ & 21.45890 & 29.79707 & 0.3296 \\
$\mathrm{r}=3$ & $\mathrm{r} \geq 4$ & 6.489120 & 15.49471 & 0.6377 \\
$\mathrm{r}=4$ & $\mathrm{r} \geq 5$ & 1.798695 & 3.841466 & 0.1799 \\
\hline
\end{tabular}

*significant at $5 \%$ level

Table 3. Johnson co integration test (Maximum Eigen Value)

\begin{tabular}{llcrc}
\hline Null Hypothesis & $\begin{array}{l}\text { Alternative } \\
\text { Hypothesis }\end{array}$ & $\begin{array}{l}\text { Maximum trace } \\
\text { statistics }\end{array}$ & 5\% critical value & $\begin{array}{l}\text { Probability (P } \\
\text { value) }\end{array}$ \\
\hline $\mathrm{r}=0$ & $\mathrm{r}=1$ & $33.96652^{*}$ & 33.87687 & 0.0544 \\
$\mathrm{r}=1$ & $\mathrm{r}=2$ & $28.28507^{*}$ & 27.58434 & 0.0406 \\
$\mathrm{r}=2$ & $\mathrm{r}=3$ & 14.96978 & 21.13162 & 0.2910 \\
$\mathrm{r}=3$ & $\mathrm{r}=4$ & 4.690425 & 14.26460 & 0.7803 \\
$\mathrm{r}=4$ & $\mathrm{r}=5$ & 1.798695 & 3.841466 & 0.1799 \\
\hline
\end{tabular}

*significant at $5 \%$ level

The result highlighted that all the chosen variables (four) are co-integrated in five vectors as shown, both Maximum Eigen value and maximum trace value say $r=5$ co integration equation. Optimal lag of VAR structure is taken 3 by using the Shewariz criterion (SC) and Akaike information criterion (AIC).

Table 4. Long run co integration equation: dependent variable is policy rate

\begin{tabular}{llll}
\hline Variables & Coefficient & Standard error & t value \\
\hline Constant & $\mathbf{7 . 7 0 1 9 8 3}$ & 0.63111 & 12.9475 \\
$\left(\pi^{a}-\pi^{e}\right)$ inflation gap & $\mathbf{0 . 1 7 6 3 0 0}$ & 0.99636 & 1.7223 \\
$\left(G D P^{a}-G D P^{e}\right)$ output & & 0.17557 & 4.4759 \\
gap & $\mathbf{0 . 0 1 8 7 2 5}$ & & 2.4884 \\
$\left(e^{a}-e^{e}\right)$ Exchange rate & & 0.09484 & \\
gap & $\mathbf{0 . 1 4 6 4 3 7}$ & & 0.0220709 \\
$\left(\mu^{a}-\mu^{e}\right)$ unemployment & & 1.05656 & \\
rate gap & $\mathbf{- 1 . 0 1 3 3 0 4}$ & & \\
\hline
\end{tabular}

*significant at 5\% level **significant $10 \%$ level 
Table 4 represents the normalized coefficient of Johansen co-integration test. Mentioned equation shows inflation gap coefficient which is 0.176 as inflation goes up from targeted level by 1 percent than nominal interest rate will be increased by 0.176 percent, but the coefficient of inflation gap is insignificant which suggests that in case of Pakistan there is a cost push inflation which is not controlled by the help of monetary measure and government takes some fiscal measures to cut down this inflation by increasing development expenditures. The coefficient of output gap shows that if actual output growth is above the targeted output growth by $1 \%$ than interest rate will be increased by $0.0187 \%$ to adjust output growth. The coefficient of exchange rate gap shows that if actual exchange rate is above the targeted exchange rate by $1 \%$ than nominal interest rate will be increased by $0.146 \%$ to adjust exchange rate to its target level because more appreciation in local currency cause to reduce export and increase import. More volatility in exchange rate also has adverse effects on current account balance of the country. The coefficient of unemployment is insignificant which suggests that monetary policy is not appropriate to adjust unemployment level in case of Pakistan, because in Pakistan structural unemployment exists which can be reduced by employing serious fiscal measures like education, provision of health facilities etc.

Analyzing the result of monetary policy reaction function, the subsequent step is to measure the stability of coefficient with the help of Rolling Window technique. The result of rolling window is shown as:

Rolling window coefficient / recursive coefficient

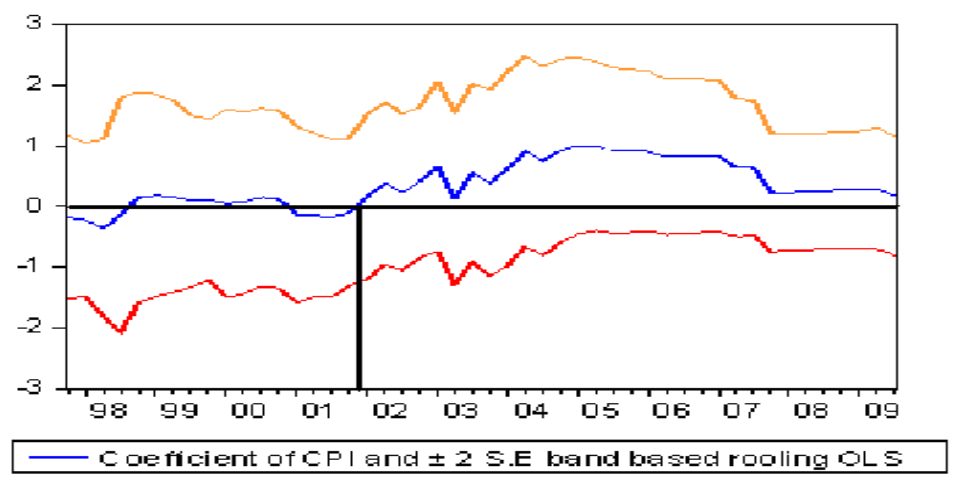

Figure 1. The coefficient of inflation gap

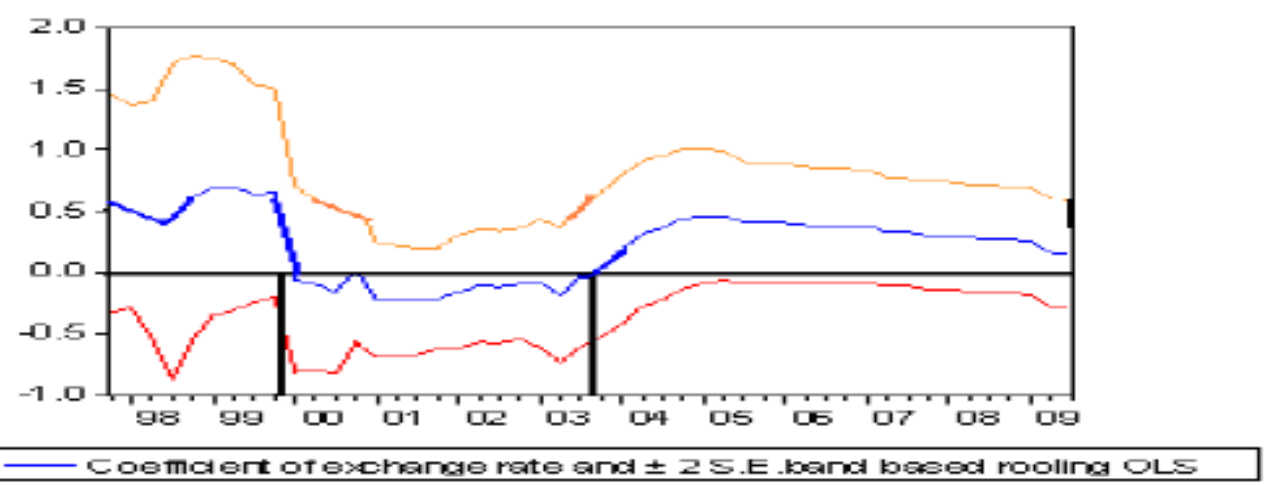

Figure 2. The coefficient of exchange rate gap

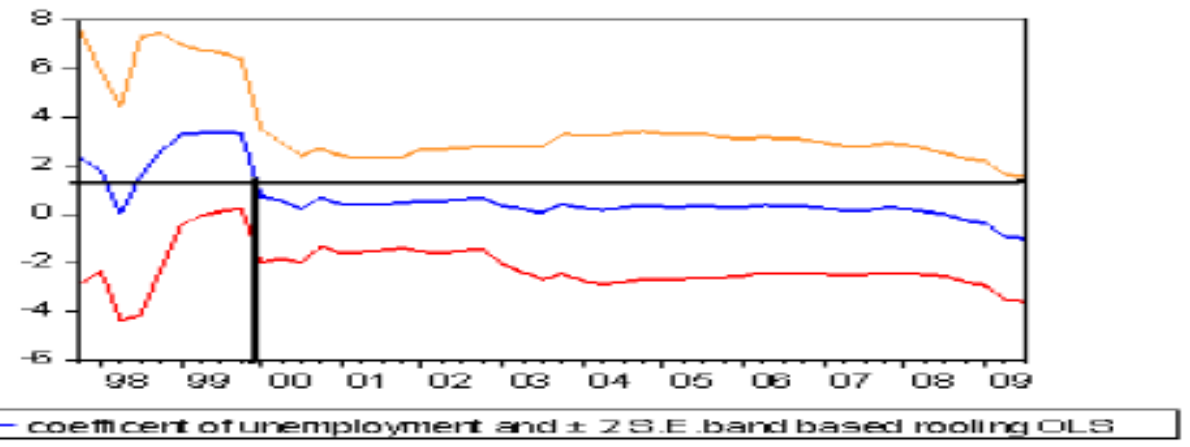

Figure 3. The coefficient of unemployment gap 


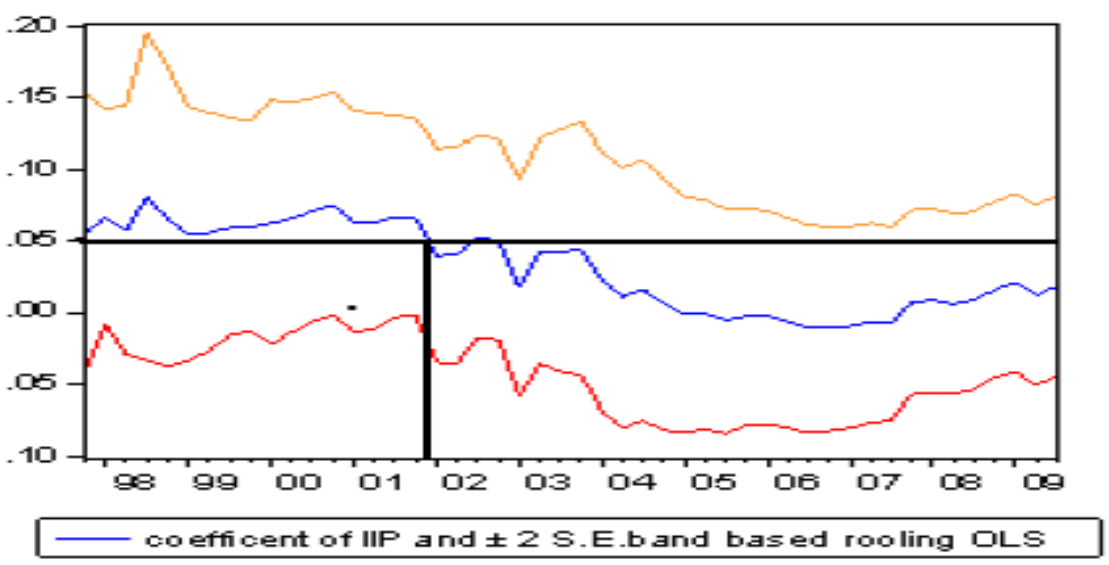

Figure 4. The coefficient of IIP which is proxy of GDP

Table 5. Descriptive statistics of long run coefficient

\begin{tabular}{ccc}
\hline & Coefficient of IIP gap & \\
\hline & Observation & Percentage \\
\hline More than 0.05 & 15 & $34 \%$ \\
Less than 0.05 & 29 & $66 \%$ \\
\hline & Coefficient of Exchange rate gap \\
\hline & Observation & Percentage \\
\hline & 15 & $34 \%$ \\
\hline Less than zero & 29 & $66 \%$ \\
\hline More than zero & Observation \\
\hline & 07 & Percentage \\
\hline & 37 & $84 \%$ \\
\hline More than one & Coefficient of Unemployment gap \\
\hline Less than one & Observation & Percentage \\
\hline & 30 & $68 \%$ \\
\hline More than zero & 14 & $32 \%$ \\
\hline Equal to zero & Coefficient of Inflation gap & \\
\hline
\end{tabular}

Figure 1 shows that before 2001 State bank of Pakistan did not pave any importance to control inflation through monetary policy but after the 2001 the coefficient of inflation gap is more than zero which shows positive gap between current and targeted inflation, SBP has shown its response by changing interest rate to back inflation rate to targeted level.

Figure 2 shows that before 2000 State bank of Pakistan has focused its monetary policy towards to stable exchange rate but from 2000 to 2003 SBP did not focus to stable the exchange rate because during this period of time the FDI (Foreign Direct Investment) was increased dramatically in Pakistan and exchange rate was stable due to the mentioned phenomenon. Again after 2003 coefficient of exchange rate gap shows that the State bank of Pakistan has adopted monetary policy towards stabilize the exchange rate as shown in Figure 2 the coefficient of exchange rate back to zero to positive range.

Figure 3 shows that before 2000 State bank of Pakistan has immensely focused its monetary policy to control the unemployment as shown in Figure 3, the coefficient of unemployment is greater than one but after year of 2000 the main target of the monetary policy has shifted from unemployment to cut down the inflation.

Figure 4 shows that before 2002 the coefficient of IIP is more than 0.05 which shows that monetary policy has given more response due to output gap but after 2002 the main focus of monetary policy was towards the inflation.

\section{Conclusion}

It is cleared that the primary objective of monetary policy which was framed by State Bank of Pakistan in recent past focused inflation targeted along with employing a host of secondary targets (reduce unemployment and stability in exchange rate etc) to accomplish its objective. The main purpose of this study is to understand the objective of monetary policy over the last 11 years. For this purpose Rolling Window method has been used to capture the objective of monetary policy. The result of Rolling Window shows that after 2002 major focus of 
monetary policy was inflation. It is found that the regression coefficients are quite weak especially the coefficient of inflation and exchange rate and reason was a cost push inflation which was not adjusted by monetary policy reaction in case of Pakistan and due to uncertainty and risk factor coefficient of exchange rate is also found insignificant. It is concluded that State Bank of Pakistan was not strictly followed the Taylor's rule while fluctuations in the economy had been occurred and the monetary policy of State Bank of Pakistan was discretionary not a Rule Based.

\section{References}

B. Bernanke, \& M. Woodford. (1997). Inflation forecasts and monetary policy. J. Money, Credit, Banking, 29, 653-684. http://dx.doi.org/10.2307/2953656

Ball, Laurence. (1999). Efficient Rules for Monetary Policy. International Finance, 2(2).

Barro, Robert J., \& David B. Gordon. (1983b). Rules, Discretion and Reputation in a Model of Monetary Policy. Journal of Monetary Economics, 12(1), 101-121. http://dx.doi.org/10.1016/0304-3932(83)90051-X

Barro, Robert, \& David Gordon. (1983a). A Positive Theory of Monetary Policy in a Natural Rate Model. Journal of Political Economy, 91, 589-610. http://dx.doi.org/10.1086/261167

Benhabib, J., S. Schmitt-Groh'e, \& M. Uribe. (2001a). The perils of Taylor rules. Journal of Economic Theory, 96, 40-69. http://dx.doi.org/10.1006/jeth.1999.2585

Bernanke, Ben S., \& Frederic S. Mishkin. (1997). Inflation Targeting: A New Framework for Monetary Policy? Journal of Economic Perspectives, 11(2), 97-116. http://dx.doi.org/10.1257/jep.11.2.97

Calvo, Guillermo, \& Frederic S. Mishkin. (2003). The Mirage of Exchange Rate Regimes for Emerging Market Countries. Journal of Economic Perspectives, 17(4), Fall. http://dx.doi.org/10.1257/089533003772034916

Engel, Charles, \& Kenneth D. West. (2006). Taylor Rules and the Deutschmark-Dollar Exchange Rate. Journal of Money, Credit, and Banking, 38, 1175-1194. http://dx.doi.org/10.1353/mcb.2006.0070

Frankel, Jeffrey A. (1994). Exchange Rate Policy. In Martin Feldstein (Ed.), American Economic Policy in the 1980s. Chicago: NBER and University of Chicago Press.

Kim, Hyeongwoo. (2006). Essays on Exchange Rate Models under a Taylor Rule Type Monetary Policy. Ph.D. Dissertation, Ohio State University.

Kydland, Finn, \& Edward Prescott. (1977). Rules Rather Than Discretion: The Inconsistency of Optimal Plans. Journal of Political Economy, 85, 473-490. http://dx.doi.org/10.1086/260580

Levin, Andrew, Volker Wieland, \& John C. Williams. (1999). Robustness of Simple Monetary Policy Rules under Model Uncertainty. In John B. Taylor (Ed.), Monetary Policy Rules. Chicago: Chicago University Press.

Malik, W. Shahid. (2006). Money, Output and Inflation: Evidence from Pakistan. The Pakistan Development Review, 46(4).

Malik, W. Shahid. (2007). Monetary Policy Objectives in Pakistan: An Empirical Investigation. Essay in PhD Dissertation, PIDE.

Reifschneider, David, \& John Williams. (forthcoming). Three Lessons for Monetary Policy in a Low Inflation Era. Journal of Money Credit and Banking.

Taylor, J.B. (2000). Recent Developments in the Use of Monetary Policy Rules. paper presented at a conference, "Inflation Targeting and Monetary Policies in Emerging Economies" at the Central Bank of the Republic of Indonesia, Jakarta, Indonesia, July 13-14.

Taylor, John B. (1993). Discretion versus Policy Rules in Practice. Carnegie-Rochester Conference Series on Public Policy, 39, 195-214. http://dx.doi.org/10.1016/0167-2231(93)90009-L

Ullrich, K. (2003). A Comparison Between the Fed and the ECB: Taylor Rules. Discussion Paper No.3-19, ZentrumfürEuropäischeWirtschaftsforschung $\mathrm{GmbH}$.

Walsh, C. (2003). Monetary Theory and Policy (2nd ed.). MIT Press.

Willett, T.D. (2003). Fear of Floating Needn't Imply Fixed Rates: Feasible Options for Intermediate Exchange Rate Regimes. Open Economies Review, 14, 71-91. http://dx.doi.org/10.1023/A:1021251303089 